\title{
Tariffs and the textile trade between Brazil and Britain (1808-1860)
}

\author{
Thales Augusto Zamberlan Pereira ${ }^{1}$
}

\begin{abstract}
The commercial treaty with Britain in 1810, along the authorization of foreign trade in ports in 1808, are among the most important institutional changes in nineteenth century Brazil. The 1810 treaty lowered tariffs for British manufactures while maintaining high tariffs in Britain for Brazilian sugar and coffee. These terms are generally viewed as disastrous for the Brazilian economy, although there is still limited quantitative information about how much the tariff affected the demand for British imports. This paper provides new qualitative and quantitative evidence on the operation and effect of Brazil's imports tariffs in the period. I find that the effect of the tariffs is different from what traditional literature assumes. First, the monetary instability in the 1820s and conflicts over product price assessment often led the de facto tariff to be higher than the 15 percent established by the treaty. Second, even with higher rates, quantitative analysis shows they did not have decrease imports of British textiles.
\end{abstract}

\section{Keywords}

Import tariff. Commercial treaty. British textiles. Brazil.

\section{Resumo}

O tratado comercial de 1810 com a Grã-Bretanha, em conjunto com a abertura dos portos em 1808, estão entre as mudanças institucionais mais importantes no Brasil durante o século XIX. O tratado de 1810 reduziu as tarifas das manufaturas britânicas enquanto manteve tarifas elevadas na Grã-Bretanha para o açúcar e o café brasileiro. Essas condições são geralmente consideradas como desastrosas para a economia brasileira, embora ainda haja informações quantitativas limitadas sobre o quanto a tarifa afetou a demanda por importações britânicas. Este artigo fornece novas evidências qualitativas e quantitativas sobre a operação e o efeito das tarifas de importação do Brasil durante esse período. A pesquisa demonstra que o efeito das tarifas é diferente do que a literatura tradicional assume. Em primeiro lugar, a instabilidade

- I am grateful to André Villela, Rafael Cariello, Thomas Kang, Kara Dimitruk, and the participants in the Latin American History Seminar of the Institute of Historical Research (University of London) for the helpful comments. This research received financial support from the British Academy Newton Mobility Grant, Application NMG2R2\100176. All remaining errors are mine.

1 Professor - Fundação Getúlio Vargas - Escola de Economia de São Paulo - End.: Rua Itapeva, 474 - Bela Vista - CEP: 01332-000 - São Paulo, SP - Brasil - E-mail: thales.pereira@fgv.br. ORCID: https://orcid.org/0000-0002-5245-1167.

Recebido: 04/07/2020. Aceito: 30/11/2020.

Editor Responsável: Leonardo Weller.

(c) (i) (\$) Esta obra está licenciada com uma Licença Creative Commons Atribuição-Não Comercial 4.0 Internacional. 
monetária na década de 1820 e os conflitos sobre a avaliação dos preços dos produtos muitas vezes levaram a tarifa de facto a ser superior aos $15 \%$ estabelecidos pelo tratado. Em segundo lugar, mesmo com taxas mais altas, a análise quantitativa demostra que não houve redução nas importações dos produtos têxteis britânicos.

\section{Palavras-Chave}

Tarifas de importação. Tratado comercial. Tecidos ingleses. Brasil.

\section{JEL Classification}

F13. N36. N76.

\section{Introduction}

In 1843, during the final days of the commercial treaty initiated in 1810, an article in the first issue of the newspaper The Economist criticized the preferential treatment given to Britain in exchange for a "liberal" commercial policy from Brazil. Brazil's main export products paid significantly higher duties compared to the British colonies. Sugar paid duties 150 percent higher and coffee 100 percent higher (The Economist 1843, 4). Only cotton had a moderate tariff, being similar to the imposed on the United States. The commercial treaty of 1810, which was initially an agreement with Portugal, continued after Brazil's independence in 1822 (Brazilian officials renewed the treaty in 1827). British imports had an official nominal tariff rate of 15 percent between 1810 and 1843, which is considered a low tariff compared to other countries Brazil traded with at the time. Thus, even the British foreign secretary George Canning argued, in 1826, that the commercial treaty was advantageous to Britain and "more onerous to Brazil."

The obvious imbalance of privileges between Brazil and Britain has led the 1810 treaty to be largely condemned by Brazilian historiography (Manchester 1964, 92; Prado Jr. 1972; Pantaleão 2003, 95; Wilcken 2005, 155). Historians such as Alan Manchester, among others, characterized the lower tariff for British manufactures as a "permanent" source of commercial losses to Brazil (Ricupero 2007, 46). Moreover, the sudden increase in the imports of British textiles during the 1810s led to the view that the treaties prevented the development of local manufactures, blocking Brazil's path to modern economic growth (Luz 1975, 23; Pryor 1965, 99).

1 The British National Archives (TNA) FO 13/25, August 1, 1826. 
Stanley Stein argued that the beginning of the textile industry in Brazil was only possible due to the higher import tariffs after 1844 (Stein 1979, 28). Despite not blaming the commercial treaties for Brazil's failure to industrialize, Celso Furtado argued that a 15 percent tariff "limited the autonomy of the Brazilian government in the economic sector" (Furtado 2006, 71, 143-44).

Even though there is a longstanding view on the negative consequences of the commercial treaties, there is still limited quantitative information on how tariffs affected Brazilian imports (especially textiles) during the first half of the nineteenth century. The main source of foreign trade in Brazil during the nineteenth century - government statistical yearbooks - provides only aggregate data after 1821 . There are no statistics for different countries and products before the 1840s (IBGE 1939; Lago 1982). Even critics of the view that Brazil was an "informal British colony," such as Stephen Haber and Herbert Klein, based their arguments on the same official sources (Haber and Klein 1997). ${ }^{2}$ Some studies that use British sources, on the other hand, do not correct for the well-known problem of outdated prices in the ledgers of imports and exports and overestimate the trade imbalance between Britain and Brazil (Arruda 2008; Imlah 1948).

By using archival evidence from the British Foreign Office, the Board of Trade, and price information from newspapers, this paper provides new information about how tariffs worked in Brazil after 1810 and discusses how imports of cotton textiles responded to changes in taxation. It extends the work of Arthur Pryor (1965) on the evolution of Brazil's tariff policy, providing evidence that the effective tariff rate in Brazil was sometimes higher than that established by the trade treaties with Britain. The higher average tariff occurred in two ways. First, the Brazilian government sometimes attempted to increase revenue by overvaluing British products at customhouses, which increased the de facto tariff rate. The government overvalued British products by taxing imported products at official prices from a book of rates, which was called pauta. The use of official values for assessing imports is known in the literature, but it has been largely ignored in the debate over the effects of trade treaties (Lima 1908, 399). ${ }^{3}$ Second, that the tariff departed from the 15 percent established by the treaty because of monetary instability that occurred during the late 1820s. As

2 See Cardoso and Faletto, Andre Gunder Frank, and Ladislau Dowbor for work that stresses the relationship between "underdevelopment" and imperialism.

3 Oliveira Lima, in fact, noticed that the use of official prices in the pauta led to custom duties higher than 15 percent. 
prices on the book of rates did not change in the short-run, sudden changes in the exchange rate had a significant impact on the average tariff level.

Figure 1 shows the average tariff rate between 1820 and 1860 calculated from two sources. The first source is from João Carneiro da Fontoura (1923), who collected data from custom-houses in Brazil. The second source is the Brazilian government custom documents. The difference in the tariff rate between these sources comes from the fact that Fontoura presents the aggregate value of all import taxes, while I use only the consumption tax (the 15 percent for British products before 1844) to calculate the average tariff from the "balanços do império". The consumption tax led to the most revenue from imports, except for the early 1840s, when the government increased some duties, like the one on alcoholic beverages (spirits), to increase revenue from trade. The instability in tariff rates during the 1820s, a phenomenon reported by multiple documents that will be presented in the next section, is striking. The sudden changes in the tariff rate suggests that the monetary instability in the early nineteenth century was the main factor behind British officials' complaints about non-compliance with commercial treaties.

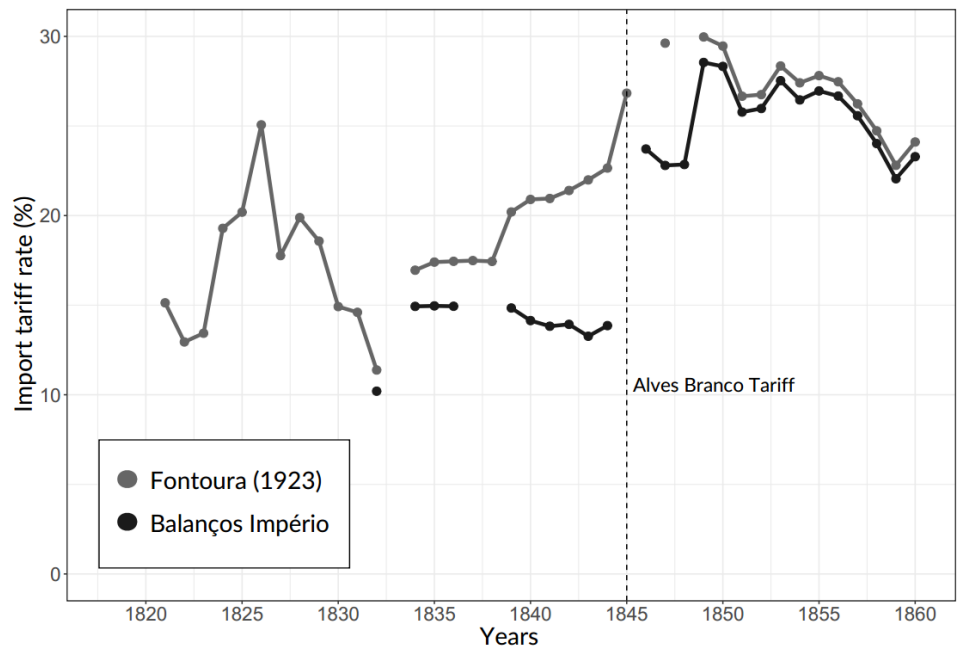

Figure 1 - Average import tariff rate in Brazil

Sources: Balanço da Receita e Despesa do Império (several years), Memória Estatística do Brasil. Relatório do Ministério da Fazenda, 1866, Center for Research Libraries. Fontoura (1923).

Note: Tariff rate from "Balanços do Império" is the ratio between import revenue (direitos de X\% de importação para consumo) and total revenue. 
Even with higher rates, however, tariffs seem to have almost no impact on the demand for cotton textiles, which was the most important British export product at the time. In fact, data from the British ledgers of trade show that exports of cotton textiles to Brazil increased after the Alves Branco tariff, which raised import duties in 1844. Textile prices collected from Rio de Janeiro newspapers also suggest that there was no significant change in the cotton goods market after 1844. Moreover, measures of import costs between 1814 and 1860 show that tariffs mattered little in explaining the changes in imports as prices of cotton textiles decreased with high British productivity growth and lower transport costs.

Section 2 presents evidence from British officials and merchants to show that the overvaluation of imported goods was a frequent point of contention between British and Brazilian authorities until the early 1830s. It is important to note, however, that this was not an organized policy by the Portuguese (and later, Brazilian) government. Higher tariff rates were as much a result of the difficulty in implementing the customs system as the need to increase revenue in the short run (Bulmer-Thomas 2003, 32). After the end of monetary instability, complaints about overvaluation decreased during the 1830s. Section 3 presents data for British exports of cotton textiles to Brazil and twenty other countries to show that the level of import tariffs had little relation to the volume of products imported. It also shows that, despite being the second largest destination for British textiles in the Americas, Brazil had a similar trade pattern in per capita terms to other South American countries. Section 4 presents different estimates for the cost of imports to explain why the demand for textile was not affected by changes in import tariffs.

\section{The commercial treaties and the book of rates}

Napoleon's invasion of Portugal led to major and unexpected changes in Brazil's foreign commerce. It initiated the end of the colonial trade monopoly in 1808 and allowed a commercial treaty with Britain two years later. José da Silva Lisboa, the future Viscount of Cairu, wrote at the time that the end of Portuguese monopoly on trade was a measure that the government adopted out of necessity, as the main Portuguese ports were under French occupation (Lisboa 1810, 608-9). With the trade blockade 
in continental Europe, Britain was a necessary commercial partner for the new government in Rio de Janeiro (Cardoso 2008). British commercial presence in Brazil was not new and some vessels had permission to trade at the port of Rio de Janeiro since 1800, but the volume of trade was still limited (Sousa 1970, 6).

Discussion about freer trade, however, was not restricted to Brazil and permeated all of Latin America at the time (Costeloe 1981). Brazil was different from the Spanish colonies in South America because of the Portuguese government's need to function after the court had to abandon Lisbon. Therefore, the urgency of finding trading partners outside continental Europe appears in several British government reports. Francis Hill, the first secretary of legation in Brazil (before the arrival of Lord Strangford), reported in March 1808 that the Prince Regent D. João was "extremely anxious to see the commercial relations between the two countries speedily settled, and on the most liberal and solid basis." D. João, immediately after his arrival in Rio de Janeiro, asked Hill if he had "any instructions to insert into a commercial treaty" because there was some expectation from the Prince's part that Britain would lower taxation on Brazilian sugar and coffee. ${ }^{4}$

The commercial treaty, therefore, was not simply a result of British pressure because the increase in trade was in the interest of local officials and attended the government's need for revenue. In fact, the October 1807 convention, which sealed the withdrawal of the court from Portugal, still limited British trade in Brazil. The convention established that British ships would have access only to the port of Santa Catarina because the Portuguese government refused to ratify parts of the document that opened other ports in southern Brazil to foreign trade (Pedreira 1994, 319). With the reduction in trade due to Europe's continental blockade, Valentim Alexande $(2007,111)$ argues that local interests in Brazil probably influenced the government to abandon initial commercial restrictions. Moreover, the Portuguese crown needed the customs revenues from imports and excessive restrictions on trade would take foreign products to other ports. Indeed, before the negotiations of the 1810 treaty had begun, Lord Strangford suggested a remodeled Methuen Treaty in 1807 whereby Portugal (and Brazil) was to admit English cotton manufactures at 20 percent ad valorem duty (not 15 percent), while Britain was to give preference to raw cotton from Brazil (Manchester 1964, 59). At the time, the British

4 TNA FO 63/63, March 30, 1808 
Board of Trade, not wanting to "stir up Portuguese resentment", argued that preference in favor of British goods would be desirable, but not "essential" (Pryor 1965, 4).

Disagreements over Brazil's commercial relations with Britain arose from the outset. The merchant John Luccock accused British merchants of becoming the "lords of customhouses" in Brazil after 1810 (Pantaleão 2003, 86). Nevertheless, with wars raging throughout Europe and North America, the higher proportional presence of British vessels in Brazilian ports would not necessarily imply a new "imperial takeover." In fact, after the initial increase in trade with the opening of ports, there is evidence that Brazilian imports from Britain were stable during the following years (Pedreira 2000, 858). The sudden changes in trade policy, however, antagonized those who had previously benefited from it and "hatred" towards British subjects grew as Rio de Janeiro merchants lost their "exclusive monopoly of imports and exports." ${ }^{5}$

Despite Britain's commercial power during this period, the enforcement of the treaties was imperfect. Britain's fragile enforcement of anti-slave trade policy is instructive of the limits to impose trade rule on Brazil. The policy enabled the British to capture Portuguese ships and condemn foreigners in British tribunals. Despite this, Brazilian authorities attempted to disregard the law that established the end of the slave trade (from 1831), which originated the expression "para inglês ver," until 1850 (Bethell 1970). ${ }^{6}$ Indeed, British pressure had a real impact on the slave trade, and slave owners and the government - which legitimized illegal trade - responded to these impositions as a way of meeting their interests (Mamigonian 2017).

To understand how Brazil's trade policy worked after 1808, therefore, it is important to first note that tariffs were not ad valorem, as it is sometimes assumed (Furtado 2006, 70; Haber and Klein 1997, 246). The 15 percent duty was levied on fixed prices set by the government, not on market prices. Thus, when D. João announced the opening of ports, the document stated that duties were "regulated by valuation made [...] of the said custom houses."7 This characteristic made the tariff resemble a specific duty in the short run, i.e., a fixed nominal levy for each physical unit imported (Crucini 1994). Changes in prices had significant impacts on tariff rates under specific custom duties and, not surprisingly, prices in

\footnotetext{
TNA FO 63/167, February 20, 1814.

6 TNA FO 63/149, 1812/1813 (Report on Slave Ships captured at the Brazilian Coast).

7 TNA FO 63/63, March 14, 1808
} 
the official book of rates, called "pauta", became an important source of dispute between Brazil and Britain at the time.

Overvaluations were a contentious topic during discussions of the treaty renewal in the 1820s and 1840s. A notable difference between the commercial treaties from 1810 and 1827 was the way to calculate the import tax rate. In the 1810 treaty, valuations for import duties were "determined and settled by an equal number of British and Portuguese merchants of known integrity and honor." ${ }^{8}$ Article XIX of the 1827 treaty, on the other hand, established that the table of valuations was supposed to be based on the current market price of commodities, which suggests an enforcement problem with the previous method. At the time, however, British products no longer had preferential rates since a new commercial treaty between France and Brazil in 1826 matched most tariffs on French products to the British (Pryor 1965, 44). ${ }^{9}$ Afterward, the Brazilian government reduced the import tariff for all nations in 1828 , ending favorable British rates. ${ }^{10}$ The issue on how to price imported goods returned with the expiration of the second treaty (1827) in November 1842 (or 1844, as the end date was also a matter of dispute) (Bethell 1970, 228). A draft proposed by Lord Aberdeen, Secretary of State for Foreign Affairs, in February 1842, proposed the extension of the treaty and suggested that, in future evaluations, "the current market price of the goods shall be taken as the principal basis: and that whenever it may be shown that an article is over-valued" the British consul can make a representation. ${ }^{11}$

The difficulty in assessing prices for different goods in a proper way is evident when we observe how the government organized official valuations. Rio de Janeiro's pauta for 1830, for example, had more than 200 pages. The section for cotton, wool, linen, and silk products had approximately 500 different classifications (Brasil 1830). Figure 2 presents an example of the level of detail of merchandise in the pauta - there were 51 different shawls categories - which suggests it was not difficult for customhouse employees to set a higher average value for cargoes. A reported practice at customhouses was to set the same tax for fine and ordinary qualities, increasing the effective tax for the latter (Lima $1908,410)$. In fact, the sheer volume of imports made it impossible to

8 Tratado de commercio, e navegação [...] (Rio de Janeiro: Impressão Regia, 1810), 18.

9 Biblioteca Nacional Digital. Diario de Pernambuco. 1827. "Das Instruções Dadas Pelo Director Geral Das Alfandegas Aos 19 de Outubro de 1826," February 19, 1827.

${ }^{10}$ Collecção Das Leis Do Imperio Do Brazil 1878, 1828 v.1

11 TNA FO 131/12 February 1, 1842. 
carry out a careful evaluation of different goods and it is reasonable to assume that many misclassifications were unintentional. For instance, 103 British vessels (from a total of 259) arrived in Rio de Janeiro in 1832, with the average vessel carrying hundreds of different products. ${ }^{12}$

Even with numerous reports, a major challenge to verify whether imports were indeed overpriced stems from the fact that textile wholesale prices were set in auctions. The official price of a specific shawl (highlighted in Figure 2) was 1200 réis a piece. The retail price, which was supposed to be considerably higher than the wholesale price, however, was 700 réis. ${ }^{13}$ Very specific products, such as a shawl, would not have much impact on the average tariff because they were imported in small quantities. This was not the case for calicos (chitas), which was the textile that had the highest import volume in the period. Using monthly data for 1830, the average retail price for calicos in Rio de Janeiro was 230 réis per covado (1.35 yard), but the prices for calicoes in the pauta ranged between 200 and 350 réis (see Figure 5). Of course, these prices are far from sufficient to confirm that the practice of overvaluing imports was common. In fact, some official prices seemed to be undervalued, which is indicative that changes in the exchange rate mattered more to determine the average tariff. Nonetheless, multiple testimonies from British consuls in Brazil, presented below, suggest that overvaluation was not unusual.

\footnotetext{
12 TNA FO 13/103, February 12, 1833.
}

${ }^{13}$ Biblioteca Nacional Digital. Diário do Rio de Janeiro, January 23, 1830, page 2: "chale de chita pequenos com franja, pinturas Francezas a 720." Pauta d'Alfandega do Rio de Janeiro, 1830, page 9: "Chale de chita escarlate franceza ou a sua imitação, dúzia $14 \$ 400$." 


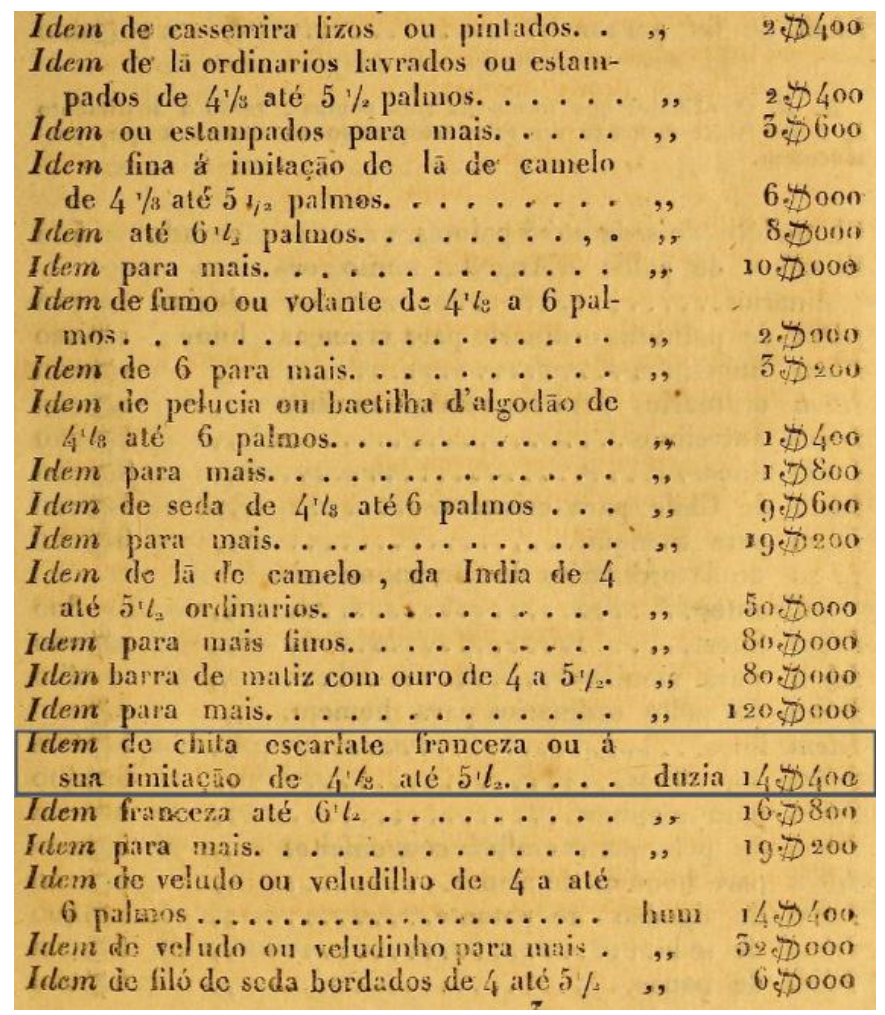

Figure 2: Example of Rio de Janeiro's Pauta da Alfândega from 1830.

Source: The John Carter Brown Library

Biased valuation of goods to increase duty incidence was a source of diplomatic discomfort between Portugal and Britain long before the government moved to Brazil. In 1789, Robert Walpole made a formal complaint that the "persons employed by the Custom House" in Lisbon were overvaluing British merchandise, which had the "mischievous effect of decreasing [...] consumption." 14 This was not an isolated complaint and documents from the Foreign Office reveal several requests during the 1790s for a reform in the "book of rates," which set the official valuations of imports. ${ }^{15}$ The practices were not exclusive to the Portuguese government. Custom duties based on official valuations, not market prices, were also standard in Spanish ports during the late $18^{\text {th }}$ century (Fisher 1981, 29). Prior to the Napoleonic Wars, Spain offered favorable treatment to Britain as well,

14 TNA, FO 63/12 May 2, 1789

15 TNA, FO 63/13 April 28, 1790 
although methods of tariff calculation varied considerably between ports and overvaluations increased revenues from taxation in times of need (Christelow 1947, 10).

There is also evidence that the practice of increasing official prices to raise revenues preceded the opening of ports in Brazil (Lugar 1980, 97). On April $1^{\text {st }}, 1808$, less than a month after the arrival of the royal family in Rio de Janeiro, English merchants established in Rio de Janeiro complained about the value of British manufacturers at the customhouse. Consul Francis Hill reported "many articles and particularly cotton goods were estimated at an increase of 100 to 400 percent above their prime cost, and consequently the duty levied upon these goods [varied] from 48 to considerably above one hundred per cent." ${ }^{16}$ Letters published in British newspapers also reported the practice, with merchants complaining in 1808 about the high duties imposed on articles from England: "these [taxes] are raised, not on the invoice prices, but on the supposed value, estimated at the Brazilian Customs." ${ }^{\prime 7}$

French merchants also noticed the higher official valuations of merchandize in the pauta (Horace Say 1839, 55). Moreover, the Bavarian travelers Spix and Martius wrote in the 1810s that, despite the official ad-valorem tax of 15 percent, Portuguese officers did not use current values "in many articles." While British import prices kept falling, the fixed prices in the pauta led the import duty on some articles to amount to " 25 per cent of their value" (Spix, Lloyd, and Martius 1824, 200). Henry Hill, the US consul in Rio de Janeiro at the time the Portuguese royal family arrived, also reported that many valuations in the "book of tariffs" did not change over time. Hill complained that products without set prices were subject to "arbitrary" valuations, "in general higher than the cost of the articles at the places of their manufacture" (Hill 1964).

James Henderson, who visited Brazil during the late 1810s, wrote that the pauta was not a "fair standard by which the real value of the article the duty is to be paid upon can be designated" (Henderson 1821, 93). Henderson also mentioned that fixed prices increased tariff rates in a time of downward trend in British import prices. Consequently, he reported that duties could amount to 25-30 percent. British officials also reported "various representations made to His Royal Highness government" in 1819

16 TNA FO 63/63, April 1; April 23, 1808.

17 British Newspaper Archives. "The Brazils", Globe - Monday 16 January 1809, p.2. 
about the "disadvantageous interpretation given to the stipulations of the Treaty by the partial and injurious explanation of the pauta." ${ }^{18}$ In fact, these reported tariffs at Brazilian customhouses were comparable to other ports in South America (Galvarriato 2008, 3). Average tariffs in Buenos Aires, Montevideo, Chile, and Peru appeared to be around 30 percent circa 1810 (Collier and Sater 2004, 45; Goebel 1938, 311, 319).

Overvaluation of imports was also not limited to Rio de Janeiro. Robert Hesketh, the first British consul in Maranhão, reported in 1813 that the local treasury board (Junta da Fazenda Real) completely disregarded the duties on British manufacturers established by the commercial treaty. Hesketh reported that customhouse officers established their own pricing guidelines on British manufactures to calculate taxes, making the average duty 30 percent, double of what was established by the 1810 Treaty. ${ }^{19}$ In 1821 the consul warned again that duties on British woolens were 30 percent due to additional fees charged by the customhouse. ${ }^{20}$ In Bahia, consul William Pennel reported in March 1822 that the local customhouse was changing the values of some products in the pauta to increase the tax rate. $^{21}$ These duties, applied disproportionately on fabrics, were higher than in the United States, a country that is generally considered more protectionist than Brazil at the time. ${ }^{22}$

Differences in international trade also affected evaluations in the book of rates in different regions. As Brazil's northern provinces frequently had a trade surplus with Britain due to the cotton export trade, exchange rates in those provinces were higher, that is, the prices of imports were lower than in Rio de Janeiro. James Henderson wrote in 1821 that printed cottons were rated in the pauta at 7400 réis a piece, but their value in Pernambuco was only 3200 réis (Henderson 1821, 94; Pryor 1965, 19-20). The businessman Diogo Ratton $(1821,5)$, in his suggestions to modify Brazilian customhouses in 1821, wrote about these price distortions and the problem of using official evaluations, "which in no way resemble each other", in different provinces.

\footnotetext{
TNA FO 268/3, December 18, 1819.

TNA FO 63/149, November 20, 1813.

20 TNA FO 63/249, January 15, 1822.

21 TNA FO 63/249, March 16, 1822.

22 Import duties on cotton and woolen manufactures in the US until 1824 were 25 percent. See Irwin $(2017,145)$.
} 
Price differences between regions increased after 1825, when the inflation of copper coins and paper money in circulation in Rio de Janeiro led to a monetary crisis that persisted until 1832. During the height of the crisis in 1830, the British consul in Rio de Janeiro stated that the mil-réis was worth 24d. in Rio de Janeiro and 48d. in Pernambuco. He reported that "£100 worth of goods shipped from England shall pay £15 duty in Rio [de Janeiro], $£ 22$ at Bahia, and $£ 30$ at Pernambuco." ${ }^{23}$ Moreover, the consul in Maranhão reported to the Foreign Office, in 1830, the "various complaints from the resident British Merchants of this province respecting the excessive duties on imports they have been compelled to pay." ${ }^{24}$ The source of discontent was the premium charged for silver coins, almost nonexistent in the market at the time due to Rio de Janeiro's monetary crisis, which had been spreading across the country (Peláez and Suzigan 1981, 46). Because custom duties in Maranhão had to be paid with silver coins, the de facto tax rate was higher (20 percent) due to the silver premium over paper money. In fact, with persistent exchange rate devaluation throughout the century, the use of gold and silver to maintain the real value of taxes from customs was used in several occasions during the nineteenth century (Villela 2005, 42).

These difficulties increased trade costs considerably. Foreign merchants complained of a "grave injustice" because products had different prices at different ports. The finance minister Marquis of Barbacena agreed to their request in 1830 to not use Rio de Janeiro's pauta in Pernambuco, especially while the "means of exchange" was not the same across the country. ${ }^{25}$ Petitions by British merchants in the early 1830s made it clear that the tariff payment system, with a silver premium "upwards of a hundred per cent", was paralyzing trade. ${ }^{26}$ Thus, during the monetary crisis, official price evaluations differed from those of the market much more on account of the country's monetary disorganization than by an alleged coordinated movement of customs officials. Merchants stated during the early 1830s that some product classifications in the pauta were undervalued because of sudden changes in the exchange rates (this variation appears in Figure 1 as well). ${ }^{27}$

23 TNA FO 268-3, September 14, 1830.

24 TNA FO 13/77, December 29, 1830.

25 TNA FO 13/87, March 23, 1831.

26 TNA FO 13/104, November 29, 1833.

27 TNA FO 268/3, September 19, 1830. 
Differences in the import tariff rate by no means diminished the fact that Britain enjoyed trade privileges with Brazil, nor does it assume that Britain did not have political leverage to impose some conditions to improve its economic position in South America. Henry Wise, who became US minister to Brazil in 1844, stated that the British government threatened to support Argentina against Brazil in the dispute for access to the Paraguay and Paraná rivers if the latter did not renew the commercial treaty (Wright 1978, 124). Indeed, these behaviors on the part of the British government increased opposition to a renewal of the commercial treaty among the public (Wright 1978, 81). In the end, even with threats of war, Brazil did not renegotiate the treaty. Evidence, therefore, does not support the view that Britain could impose any trade conditions on Brazil and, because of the commercial treaties, dominated its market after 1810 . Reports show that British merchants "no longer attached much importance to their judicial privileges in Brazil" during the early 1840s, as Britain's economic superiority over its competitors was evident (Bethell 1970, 233).

\section{The British textile trade with Brazil}

Despite estimates that approximately 50 percent of all imports in Latin America before 1850 came from Britain, there is still limited research on how the Brazilian cotton goods market behaved at that period (LlorcaJaña 2012, 4; Platt 1973). Brazil's official bilateral trade statistics with Britain are only available after 1842. Scarcity of foreign trade data has therefore been an important factor that limited our understanding of trade liberalization after 1808 (IBGE 1939, Ano V:1358). This led some earlier studies to speculate that Brazil was a "sleeping giant" during the first decades of the nineteenth century, a stagnant economy overflowed by British imports (Batista Jr 1980; Fishlow 1980). This vision of a fundamentally unequal trade, however, relies on the idea that Britain closed its markets to Brazilian products and that sugar and coffee had no alternative ports, especially where trade could be more profitable (Simonsen 1967, 397). Provincial trade data, however, show that most northern provinces had trade surpluses with Britain after 1808 from the raw cotton trade. Furthermore, Britain had exceptionally low coffee consumption and, therefore, sugar planters were initially the most adversely affected by higher duties. Even with the restrictions of British trade, sugar and coffee had 
higher demand from other markets. During the early 1830s, 36 percent of all sugar imported in Hamburg came from Brazil while coffee was exported in large quantities to the United States (Sturz 1837, 98).

The view that trade between Brazil and Britain was quite uneven after 1808 also comes from the calculation of the trade balance by José Jobson Arruda, who used data from the British Ledgers of Imports and Exports between 1808 and 1821 (Arruda 2008, 55-69; Ricupero 2007). There are two problems with Arruda's estimations. First, he uses the "official values" of the British ledgers, which reported fixed price rates from 1696 (Imlah 1948). These outdated prices overestimate the value of cotton textiles because they do not take into account the substantial increase in productivity that lowered textiles prices during the first decades of the Industrial Revolution (Harley 1998). They also underestimate the value of Brazilian exports: in official values, the average value of raw cotton imports from Brazil between 1809 and 1820, a period which became known as the cotton boom years, is $£ 648,441$. Market prices of Brazilian cotton in Liverpool acquired from newspapers, however, shows that the average reaches $£ 1,716,237$. Secondly, as Jorge Pedreira notes, Arruda adds bullion transactions to the comparison, which distorts bilateral trade even more (Pedreira 2000, 855).

The increase in the availability of foreign products after 1808 is also not enough to evaluate the impact of freer trade on local markets because there is no evidence that there was an inelastic demand for British products. In fact, the "flood of British products" argument is based largely on reports that describe the arrival of exotic and useless products, such as ice skates, at Brazilian shores after 1808 (Wilcken 2005, 152; Pantaleão 2003, 88). John Mawe (1821, 455-57), who was probably the first to report speculators sending ice skates to Brazil, made clear that these and other exotic products were unsalable. Indeed, stories about British merchants selling ice skates in tropical regions also appeared for the West Indies at the same time, suggesting that it could be an illustrative way to describe the commercial euphoria of the period (Turner 1897, 99).

Additional evidence shows that British merchants had no guaranteed profits when shipping products to Brazil. In a representation to the Portuguese government from September 1808, a committee appointed by the Society of British Merchants residing in Rio de Janeiro stated that they faced significant losses because "a number of goods unsuitable" for 
Rio de Janeiro's market arrived and could not be transported to other ports in a profitable manner due to transit duties. ${ }^{28}$ Even during Portugal's period of trade monopoly, merchants sometimes had their sales frustrated at Brazilian ports and had to go after other markets. ${ }^{29}$ Therefore, according to Jorge Pedreira $(1994,331-32)$, when the 1810 treaty was signed, the "myth of the great South American market" had mostly been dispelled. ${ }^{30}$ Between 1806 and 1809, the "mirage" promising large consumer markets for British products proved unrealistic, and effective sales in River Plate were also much lower than expected (Socolow 1978).

Brazil, nevertheless, was Britain's largest market in South America and cotton goods were by far its most important product, accounting for "nearly half of all British exports in the first half of the nineteenth century" (Davis 1979, 14). The travelers Spix and Martius reported that people in Brazil preferred cotton to other types of fabrics, and that there was little demand for linens, which were "not much used by the Brazilians" (Spix, Lloyd, and Martius 1824, 290). Cotton textiles represented 44 percent of British exports to Brazil in the years preceding independence and continued to be the most important category throughout the nineteenth century. ${ }^{31}$ During the late 1840 s cotton goods still represented 35 percent of all imports into Brazil. Woolens and flour, the next products in importance, represented 7 and 6 percent of total trade, respectively. ${ }^{32}$

Information from trade ledgers (Figures 3 and 4) confirms that Brazil was an important market for British cotton textiles. Brazil made up, on average, 8 percent of the total British cotton textile trade and 20 percent of the American trade, being second to the United States. It is interesting to note that, regardless of the changes in tariff rules under different commercial treaties, the Brazilian market share remained constant throughout the period. Moreover, the US became the second largest textile producer in the world by the mid-nineteenth century while it was the most important consumer of British textiles in the Americas (Farnie 1979, 180).

28 TNA FO 63/63, September 1808.

${ }^{29}$ As an example, several silk products sent from Portugal to Bahia had no buyers in 1800 (Sousa 1970, 81).

${ }^{30}$ In the southern ports, British merchants also faced the problem of collecting return cargoes that could be sold on the British market, which reduced the overall trade (Sturtz 1837).

${ }^{31}$ Diário do Rio de Janeiro, 22 January, 1842.

32 In Bahia, cotton goods represented 38 percent of imports in 1840 "Commerce and Navigation of Brazil," Hunt's Merchants' Magazine and Commercial Review, 1848, 19 edition, 321, Hathi Trust Digital Library.. 
Figure 3 presents the shares of cotton textiles exports, which are the sum of calicos (white and printed), muslins (white and printed), and fustians. Among those products, calicos were the most important fabric, representing 90 percent for Brazilian imports of cotton textiles and 76 percent for the United States. The predominance of calicos is emblematic of the possible impact that trade liberalization had on local markets. Calicos were one of the products that had the greatest productivity increase in Britain at the turn of the nineteenth century (Styles 2016; Riello 2013). These textiles had a higher quality than what was produced in Brazil, as coarse cotton goods from Minas Gerais were one of the few products domestically available at the time (Spix, Lloyd, and Martius 1824, 302). Textile production in Brazil, therefore, did not face competition from the importation of British cloth because it catered to a different market (Libby 1991). The cotton industry in Portugal did not focus on spinning or weaving - there were few looms in the country and Portugal imported cotton yarn from Britain - but on stamping of white cloth from India (Pedreira 1994, 290-91). Moreover, British competition implied that even textile producers in the US found it profitable to produce only very coarse yarns during the 1810s (Temin 1988, 897). Merchants in Buenos Aires at the time stated that "English goods were more attractive to the consumer because of their better perfection, their greater neatness and splendor, their longer-lasting quality, and their fairer prices" (Socolow 1978, 130). This productivity gap only widened with improvements in shipping technology and declining freight rates after 1815 (North 1958, 544; Kelly and Ó Gráda 2018). 


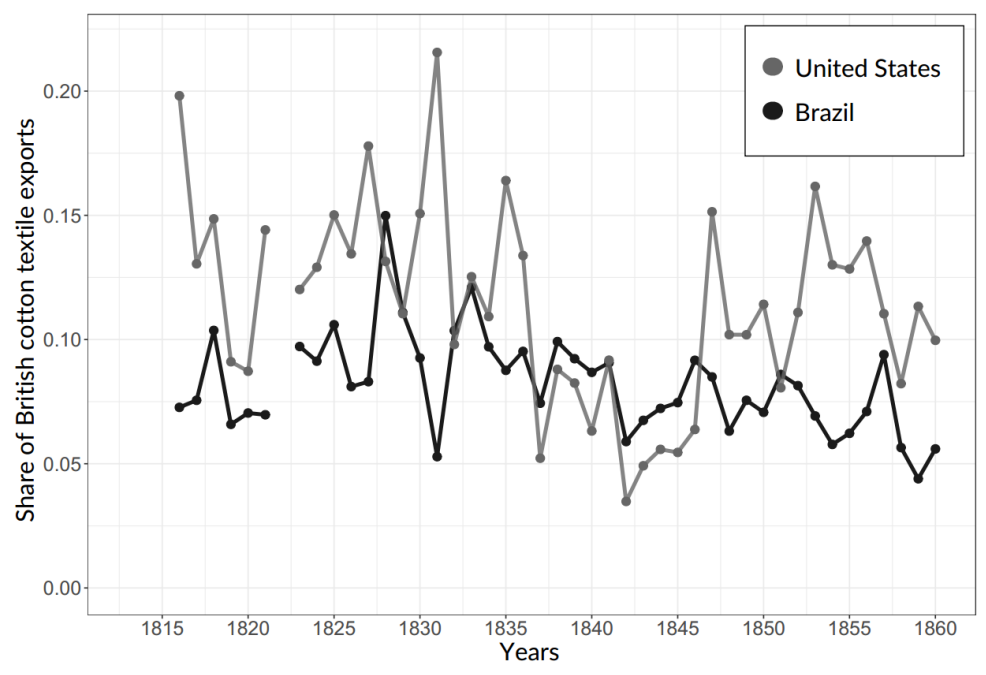

Figure 3: Brazil and the United States share in total British exports of cotton manu factures, 1814-1860.

Source: TNA CUST 9

Note: Shares correspond to the total amount of British cotton textiles exported.

Demand increased substantially with cheaper textiles and Brazil imports of calicos increased from 12.8 million yards in 1815 to 153.8 million in 1860. In comparison, the estimated production of cotton fabrics (most of them coarse cloth) in Brazil was only 2.9 million yards in 1866 (Rego 1869, 2:35). ${ }^{33}$ Figure 4 presents the amount of cotton exports to Brazil and the total value of these exports to Brazil and the United States. The stability of the total export value, while the quantity continued to grow, indicates how much prices declined in half a century. The information about the value of British cotton manufactures exported to Brazil is from the "declaration of the merchants' exports," not the official values (both FOB prices). Different from the import ledgers, the British export ledgers have two different sets of information about total values: the "official value" and another based on the declaration of merchants. In the trade ledgers, the difference between official prices and declared values is clear after 1820, when the gap between them increases as prices of cotton textiles decreased with productivity growth (Esteban 1995; 1999; Harley 1998; 1999). However, we should be careful with the absolute magnitudes in Figure 4 , since textile prices in the early nineteenth century are notoriou-

331 yard $=0.9144$ meter, 1 vara $=1.1$ meter. 
sly unreliable (Hoppit 1990, 181). As customhouses in Brazil overvalued the price of British imports to increase tariff rates, merchants in Britain could underreport the value of their articles in order to avoid higher taxation (Platt 1971, 126).
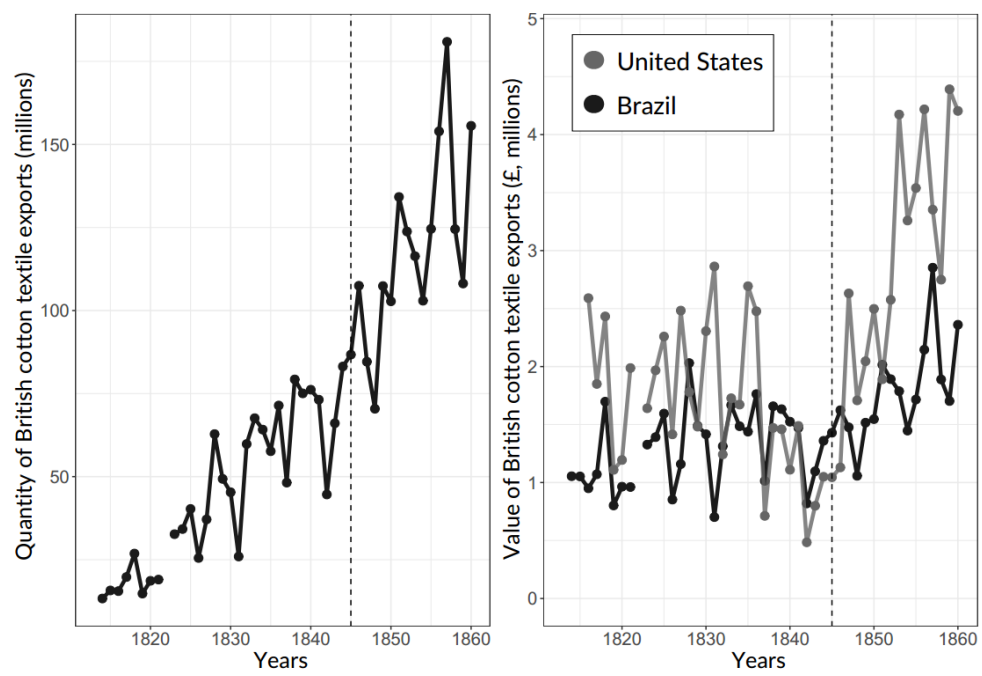

Figure 4: Quantity and value of British cotton manufactures exports to Brazil.

Source: TNA CUST 9

Note: Free on board (FOB) prices, which do not include transport costs. The vertical dotted line is the Alves Branco tariff reform. The figure on the left (in yard) includes only the most common cotton textiles: calicoes (white or plain, and printed) and muslins (white or plain, and printed).

Brazil and the United States were the largest markets for British cotton exports in the Americas mainly due to the size of their population. To analyze the consumption of cotton goods in per capita terms, Table 1 compares Brazil with other 20 countries listed in the British ledgers of trade (TNA CUST 9) using annual data between 1820 and 1860. The data show that the differences in textile imports were a combination of local manufacturing development and different trading partners. France and Spain are a case in point, as both had low textile trade with Britain due to a history of conflicts and attempts to develop local cotton manufacturing. An opposite example is Holland, whose higher export per capita numbers were due to its role as a re-export port. The most notable difference, however, was the trade pattern between Europe and the Americas, which is expected, given different levels of economic development. 
Table 1 - British exports of cotton manufactures (£) per 1,000 people.

\begin{tabular}{lrrrr}
\hline & $1820 \mathrm{~s}$ & $1830 \mathrm{~s}$ & $1840 \mathrm{~s}$ & $1850 \mathrm{~s}$ \\
\hline Argentina and Uruguay* & 440.2 & 433.1 & 330.8 & 437.3 \\
Brazil & 263.2 & 242.4 & 198.7 & 246.1 \\
Chile & 335.2 & 460.0 & 404.5 & 402.3 \\
Cuba & 173.2 & 251.7 & 209.7 & 297.7 \\
Jamaica & 1479.8 & 941.4 & 654.8 & 397.1 \\
Mexico & 39.3 & 41.8 & 30.2 & 37.6 \\
Peru & 114.5 & 157.2 & 199.3 & 256.7 \\
United States & 156.6 & 125.6 & 65.7 & 120.1 \\
Venezuela & 32.0 & 0.0 & 50.9 & 140.5 \\
\hdashline Belgium & 93.3 & 53.8 & 37.4 & 24.4 \\
Denmark & 13.3 & 3.9 & 10.7 & 29.0 \\
France & 0.4 & 3.5 & 4.1 & 5.0 \\
Germany & 69.6 & 44.3 & 29.4 & 32.7 \\
Holland & 224.0 & 227.2 & 182.5 & 178.2 \\
Italy & 46.3 & 45.7 & 35.8 & 38.7 \\
Norway & 19.0 & 12.5 & 18.2 & 25.8 \\
Portugal & 215.6 & 180.7 & 165.8 & 163.5 \\
Spain & 6.8 & 3.8 & 0.4 & 6.5 \\
Sweden & 0.6 & 2.9 & 1.8 & 4.6 \\
Turkey & 35.6 & 83.6 & 120.7 & 193.1 \\
\hline
\end{tabular}

Sources: TNA CUST 9, Maddison Project (2018)

Note: The exports are decennial averages. Population is in thousands. Between 1827 and 1845, Argentina and Uruguay appear as "States of Rio de la Plata".

The evidence presented in Table 1 does not support the argument that changes in import tariffs (especially after 1844) altered trade patterns between Britain and Brazil. By comparing with other countries in Latin America, one can see that Brazil was not an outlier in any period and its textile trade was similar, in per capita terms, to Argentina, Chile, Cuba, and Uruguay. The appendix presents a cluster algorithm, using data from Table 1 and GDP per capita for 1820 and 1850, which confirms that the Brazilian trade pattern resembled other countries from South America (Tibshirani, Walther, and Hastie 2001). The only countries in Latin America that had a noticeable different trade pattern with Britain were Mexico and Venezuela. The cotton textile sector in Mexico, due to its earlier textile industry development compared to other places in Latin America, managed to survive even with foreign competition during the first half of the nineteenth century (Galvarriato 2008). Lastly, Table 1 
also shows that the textile trade remained relatively stable during several decades, regardless of differences in freight costs between ports (Stemmer 1989).

\section{Effects of tariffs on British imports}

The relationship between tariffs and manufacturing development during the nineteenth century is a central theme in economic history. Protectionism remained strong after the end of the Napoleonic Wars, with countries such as France, Russia, Spain, Norway, and the AustriaHungary empire prohibiting the import of a wide range of manufactured goods (Baldwin 2016, 56). Britain implemented the Corn Laws while other countries raised their tariffs as a way to increase revenue and address domestic demands for protectionism (Ward 2004; Williamson 1990). Textile manufacturers in the United States lobbied Congress for tariff protection after 1815, when there was an increase of British imports following the war (Rosenbloom 2002; Lind 2012). The Tariff of 1816 had lower rates for finer cloths, since at the time the United States produced cloths with lower counts (a measure of quality) than Britain (Temin 1988, 897). Nonetheless, tariffs for cotton textiles remained high in the United States until 1846 (Harley 1992).

The use of protectionist policies by European countries and the United States have stimulated a long debate about what the outcome of similar policies would be in Latin America (Coatsworth and Williamson 2004; Tena-Junguito 2010). The case of Brazil stands out because Portugal prohibited the production of high-grade textiles in the colony between 1785 and 1808 (Alden 1987, 308). However, even in the absence of such law, it would be unlikely that the sector would be able to compete with the British level of productivity. The "superior technical and financial resources" of British commerce already outweighed its trade privileges decades before the Brazilian ports opened (Christelow 1947, 27; Temin 1997). As a matter of fact, even in regions that had natural protection from foreign trade due to the high costs of transportation, such as Cuzco, the "invasion" of foreign goods was a source of dissatisfaction for local producers during the late 1820s (Walker 1999, 149). Additional evidence from other Latin American countries reinforces the idea that import of British 
products were not affected by tariffs. Chile is a case in point, as even with clearly distinct tariff regimes before and after 1834, it had no noticeable changes in its textile imports from Britain, as Table 1 shows (Collier and Sater 2004, 60).

The excessive focus on commercial treaties, therefore, has led to the interpretation that Britain relied on lower tariffs more than on productivity differences to obtain commercial advantages (Platt 1973; Miller 1995). Tariffs, however, are far from being a sufficient condition for the development of the manufacturing sector (Irwin 2017; Martínez-Galarraga and Prat 2016). In fact, these issues were recognized by the government at the time. A commission organized to evaluate the impact of the 1844 tariff reform argued that "the backwardness of Brazilian industry was due neither to the lack of adequate tariff protection nor to competition from foreign products" (Stein 1979, 27). The commission argued that the backwardness of Brazil was due to reasons common to the development process of other countries, such as shortage of capital and poor worker education. Even Friedrich List, an author commonly used in arguments in favor of protecting infant industries, argued during the 1830s that tariffs could only produce "expensive goods of poor quality" in South America due to the lack of preexisting conditions - especially human capital - for industrialization (Boianovsky 2013, 661).

Price data suggest that the emphasis on tariffs to understand consumption patterns in Brazil is also misplaced. Figure 5 presents retail prices for calicos (chitas por covado), collected from Rio de Janeiro newspapers, between 1822 and 1855. ${ }^{34}$ I also collected monthly data for exchange rates to show the prices in the British currency, which had a more stable value during the period. As argued before, retail prices for textiles present a series of challenges due to the range of classifications. Nonetheless, the series shows a trend that is consistent with other sources. First, there were large fluctuations between 1825 and 1831, when Rio de Janeiro was amid a monetary crisis. The large drop in prices in 1827 is consistent with reports from British consuls in Brazil arguing that the exchange rate instability brought "ruinous losses" to some British merchants (Pryor 1965, 78). The period until the mid-1830s also had a higher average price than the subsequent period, when Brazil's currency stabilized and ocean freight rates declined (Harley 1988). Lastly, there are no persistent increases in prices after the Alves Branco tariff, in 1844.

$\overline{34}$ Newspapersreported calicoswith a wide range of prices, i.e., "from 80 to 200 reis". Iusetheaverage price. 


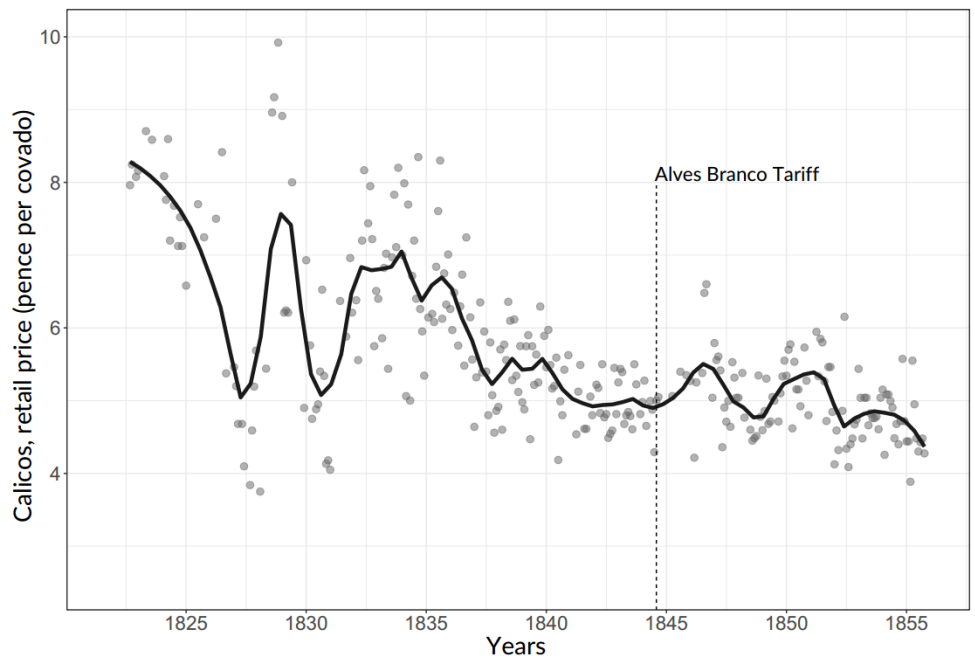

Figure 5: Retail price of calicos in Rio de Janeiro, 1822-1855 (pence per covado)

Sources: Diário do Rio de Janeiro (Biblioteca Nacional Digital, Brasil).

Note: Calicos is "chitas por covado". Covado $=1.35$ yard. Exchange rates are from Diário do Rio de Janeiro and Jornal do Commercio (RJ).

As additional evidence for the hypothesis that the tariff level had no significant impact on the demand for British textiles, Table 2 presents structural break estimates showing that textile exports to Brazil in fact increased after the Alves Branco tariff (Bai and Perron 2003). From an annual average of $£ 1,309,800$ between 1815 and the late 1840 s, the value of cotton exports to Brazil more than doubled in the following decades. The increase in imports after 1850 and 1863 is consistent with André Villela's (2005) analysis of tariff policy in Brazil during the second half of the nineteenth century, which shows how little tariff changes affected import costs. Nevertheless, it is important to note that the real impact of the Alves Branco tariff is difficult to measure, as the period is full of other institutional changes, from banking organization to commercial laws (Levy and Andrade 1985, 26). Moreover, the increase in cotton textile exports to Brazil is in line with the overall expansion of British foreign trade during the 1850s (Bairoch 1972, 238). 
Table 2 - Break Points in British exports of cotton textiles to Brazil, 1815-1879 (£000)

\begin{tabular}{|c|c|c|}
\hline Break year (Ti) & Boundary for $90 \%$ confidence interval & Proportional change \\
\hline 1850 & [1845 - 1852] & $+55.2 \%$ \\
\hline 1863 & [1862 - 1865] & $+57.6 \%$ \\
\hline Parameter & $\beta$ & Corrected Standard Errors \\
\hline$\beta 1$ & $1,309.8$ & $64.14^{\star \star \star}$ \\
\hline$\beta 2$ & $2,034.0$ & $140.68^{\star \star \star}$ \\
\hline$\beta 3$ & $3,206.7$ & $90.23^{* * *}$ \\
\hline$R^{\wedge} 2: 0.809$ & & Number of breaks selected by: \\
\hline$F(3,62): 87.59$ & & $\sup F(L+1 / L)$ test $=2$ \\
\hline$n=65$ & & Sequential procedure $=2$ \\
\hline *** significant at $1 \%$ level & & Repartition procedure $=2$ \\
\hline
\end{tabular}

Notes: The method for the structural breaks is from Bai and Perron (2003). With a 10 percent trimming on the series, the minimum interval length between breaks is 6 years. Breaks are for the last date of the old regime. Output from the estimation of the model selected by the sequential method.

A third way to measure the importance of the tariff level for the demand of imported products is to estimate the cost of imports, using information on tariff levels $(\tau)$, nominal exchange rates $(E)$, price of imports $\left(P_{i m p}\right)$, and local prices $\left(P_{\text {local }}\right)$ (Villela 2005). Since there are no series for wholesale prices of British textiles in Brazil, I use the declared value of cotton exports for Brazil from the British trade ledgers as a proxy. As Platt (1971, 124) argues, however, the system of declared values "depended on the knowledge and application of shippers' clerks, and in the case of goods sent to the country on consignment [...] (without invoice or statement of prices) the consignee was naturally unable to give an immediate price." Nonetheless, despite a debate about the rate of change in British cotton textile prices for early nineteenth century, evidence suggests that they dropped substantially during the period (Harley 1998). The use of declared values as import prices also assumes that transport costs were constant during the whole period, which was not the case. As an example, trade information between Maranhão and Liverpool shows that freights fell by half between 1820 and 1850 (Pereira 2017, 184). Moreover, better packaging for textiles reduced transport costs substantially after 1820, reducing textile prices in foreign markets even more (Llorca-Jaña 2012, 7). The calculation in Figure 6, therefore, understates the actual change in trade costs.

$$
\text { Cost of imports }=\frac{P_{\text {imp }} * E *(1+\tau)}{P_{\text {local }}}
$$


The estimated cost of textile imports in Brazil is shown in Figure 6. The black line uses the 15 percent tariff rate until 1844, when the Alves Branco tariff increased to 30 percent for textiles. The grey line assumes a counterfactual of a 30 percent tariff for the whole period to show that the most important components in the cost of imports were the exchange rate (volatility) and relative prices (trend). This is clear in the years between 1825 and 1830, when a large devaluation of the mil-réis stopped the downward trend of the series. For local prices, I use the price index from Eulalia Lobo (1971), which captures changes in food prices in Rio de Janeiro. Food prices, however, were more volatile than prices for manufacturing goods and can bias the results. Since Lobo's inflation estimate is higher than the other estimates for the second half of the nineteenth century, such as Mircea Buescu $(1979,26)$, I constructed an alternative series (P) assuming that the rate of price variation between each year was half of what was estimated by her. Thus, while in the alternative series $(\mathrm{P})$ prices doubled between 1820 and 1850, prices increased approximately three times during the same period in Lobo's estimates. This exercise shows that, even with lower inflation and a 30 percent tariff for the whole period, there would be a substantial reduction in the cost of imports.

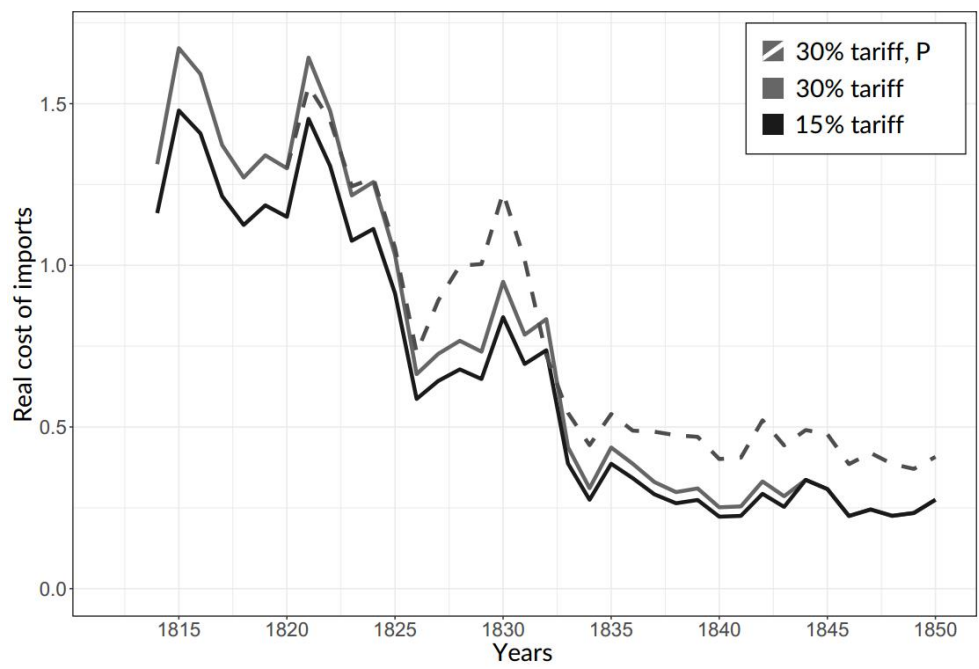

Figure 6: Real cost of imports from Britain, 1814-1850

Sources: Lobo (1971), TNA CUST 9,

Note: Domestic prices between 1814 and 1819 are from Johnson (1973) 


\section{Conclusions}

The opening of ports and the subsequent commercial treaty with Britain radically changed foreign commerce in Brazil during the early nineteenth century. The first contribution of this paper is to explain in more detail how tariffs worked in Brazilian ports. The reason for analyzing how customs received imports in the period is that a frequent misconception regarding the commercial treaties is to assume that the 15 percent tariff rate was on market prices, not official prices. The use of the book of rates, however, led the average import tariff to change substantially during periods of high volatility in the exchange rate, as was the case during the 1820s. Archival documents provide evidence that the use of official prices has caused a series of conflicts between British merchants and the Brazilian authorities. There was no organized attempt by the Brazilian government to overvalue British textiles, but several documents show that such practice occurred.

The second contribution comes from testing if tariffs had any effect on textile imports. The use of protectionist policies by European countries and the United States have stimulated a long debate about what the outcome of similar policies would be in Latin America. This paper shows that, with increasing British productivity and lower transport costs, tariff levels explain little of the overall import costs in Brazil. The Alves Branco tariff, which is usually regarded as a protectionist turn in Brazil's trade policy, did not reduce the import of cotton textiles. Indeed, even with changes in trade rules over six decades, the share of the Brazilian market for British cotton manufactures was stable throughout the period. Moreover, despite being the second largest market for British textiles in the Americas, exports per capita of cotton manufactures to Brazil were similar to other South American countries, such as Argentina, Chile, and Uruguay.

\section{Appendix}

To test if the pattern of British exports to Brazil was similar to other countries, I use a cluster analysis to find subgroups within the data from the British Ledgers of Exports, collected at the British National Archives. Among the many clustering methods available (see James et al. 2013, chap. 
4), I use K-means, which is one of the most common classifiers. The idea behind the method is, after choosing the number of clusters, to select objects that are as similar as possible (high intra-class similarity) given a set of variables. Therefore, in addition to the average exports per decade for twenty countries, I use GDP per capita estimates for 1820 and 1850 to control for income differences between countries, as income affected the demand for textiles. To specify the number of groups for the K-means algorithm, I use the GAP method to estimate the optimal number of clusters (Tibshirani, Walther, and Hastie 2001). Figure Al shows that the GAP method selects two groups, and the K-means algorithm puts Brazil with other Latin American countries. Brazil, therefore, did not have a pattern of trade distinct from its neighbors such as Argentina and Uruguay.

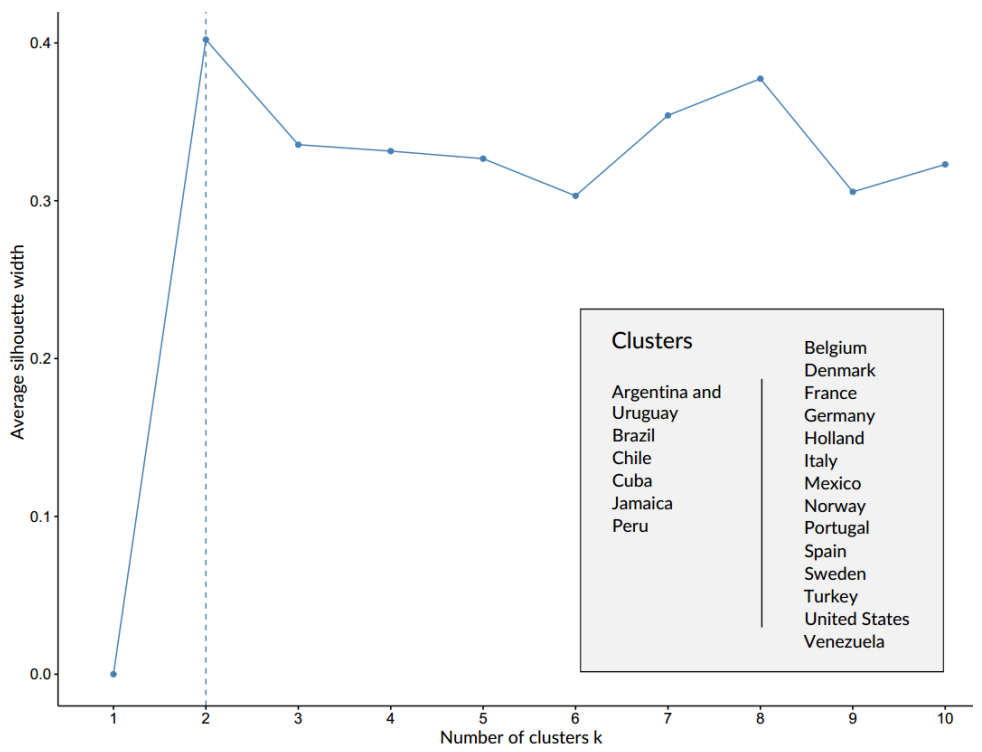

Figure Al: Optimal number of clusters (Gap Statistical Method).

Source: TNA CUST 9; Maddison Project (2018); Tibshirani, Walther, and Hastie (2001).

Notes: The variables used to estimate de clusters are the British exports of cotton manufactures per capita, presented in Table 1, and GPD per capita for 1820 and 1850, from the Maddison Project. 
Table Al - Imports in Brazil (réis)

\begin{tabular}{|c|c|c|c|c|c|}
\hline Date & $\begin{array}{c}\text { Import } \\
\text { revenues }\end{array}$ & Total Revenues & $\begin{array}{l}\text { Share } \\
\text { import }\end{array}$ & Total imports & Import tariff \\
\hline 1832 & $3,291,937,933$ & $11,118,760,686$ & 0.30 & $32,146,000,000$ & 0.10 \\
\hline \multicolumn{6}{|l|}{1833} \\
\hline 1834 & $5,418,567,095$ & $12,282,254,731$ & 0.44 & $36,285,000,000$ & 0.15 \\
\hline 1835 & $5,471,629,593$ & $14,576,388,856$ & 0.38 & $36,577,000,000$ & 0.15 \\
\hline 1836 & $6,154,579,702$ & $14,053,610,315$ & 0.44 & $41,196,000,000$ & 0.15 \\
\hline 1837 & & & & $45,320,000,000$ & \\
\hline 1838 & & & & $40,757,000,000$ & \\
\hline 1839 & $7,339,309,612$ & $14,856,538,202$ & 0.49 & $49,446,000,000$ & 0.15 \\
\hline 1840 & $7,403,843,837$ & $15,759,705,794$ & 0.47 & $52,359,000,000$ & 0.14 \\
\hline 1841 & $7,981,028,533$ & $16,133,170,540$ & 0.49 & $57,727,000,000$ & 0.14 \\
\hline 1842 & $7,806,806,410$ & $15,180,255,079$ & 0.51 & $56,041,000,000$ & 0.14 \\
\hline 1843 & $6,718,121,430$ & $13,284,729,028$ & 0.51 & $50,640,000,000$ & 0.13 \\
\hline 1844 & $7,662,812,308$ & $17,851,915,836$ & 0.43 & $55,289,000,000$ & 0.14 \\
\hline 1845 & & & & $55,228,000,000$ & \\
\hline 1846 & $12,378,425,367$ & $21,630,515,835$ & 0.57 & $52,194,000,000$ & 0.24 \\
\hline 1847 & $12,708,596,243$ & $22,514,883,919$ & 0.56 & $55,740,000,000$ & 0.23 \\
\hline 1848 & $10,819,654,567$ & $20,304,395,232$ & 0.53 & $47,350,000,000$ & 0.23 \\
\hline 1849 & $14,720,886,614$ & $25,204,279,312$ & 0.58 & $51,570,000,000$ & 0.29 \\
\hline 1850 & $16,758,488,434$ & $26,977,836,430$ & 0.62 & $59,165,000,000$ & 0.28 \\
\hline 1851 & $19,826,184,187$ & $31,532,764,693$ & 0.63 & $76,918,000,000$ & 0.26 \\
\hline 1852 & $24,121,338,762$ & $35,786,821,853$ & 0.67 & $92,860,000,000$ & 0.26 \\
\hline 1853 & $24,042,903,922$ & $36,391,032,008$ & 0.66 & $87,332,000,000$ & 0.28 \\
\hline 1854 & $22,708,117,691$ & $34,516,445,058$ & 0.66 & $85,839,000,000$ & 0.26 \\
\hline 1855 & $22,958,161,115$ & $35,935,178,482$ & 0.64 & $85,171,000,000$ & 0.27 \\
\hline 1856 & $24,745,644,275$ & $38,634,356,105$ & 0.64 & $92,779,000,000$ & 0.27 \\
\hline 1857 & $32,025,391,471$ & $49,156,414,724$ & 0.65 & $125,227,000,000$ & 0.26 \\
\hline 1858 & $31,288,211,119$ & $49,747,007,187$ & 0.63 & $130,264,000,000$ & 0.24 \\
\hline 1859 & $28,069,705,256$ & $46,919,995,473$ & 0.60 & $127,268,000,000$ & 0.22 \\
\hline 1860 & $26,321,853,903$ & $43,807,340,450$ & 0.60 & $113,028,000,000$ & 0.23 \\
\hline
\end{tabular}

Sources: Balanço da Receita e Despesa do Império (several years), Memória Estatística do Brasil. Relatório do Ministério da Fazenda, 1866, Center for Research Libraries. 


\section{References}

Alden, Dauril. 1987. "Late Colonial Brazil, 1750-1808." In Colonial Brazil, edited by Leslie Bethell, 284-343. Cambridge ; New York: Cambridge University Press.

Alexandre, Valentim. 2007. “A Carta Régia de 1808 e Os Tratados de 1810.” In A Abertura Dos Portos, edited by Luís Valente de Oliveira and Rubens Ricupero, 100-121. São Paulo: Senac.

Arruda, José Jobson de Andrade. 2008. Uma colonia entre dois impérios: a abertura dos portos brasileiros 1800-1808. Cátedra Jaime Cortesão.

Bai, Jushan, and Pierre Perron. 2003. "Computation and Analysis of Multiple Structural Change Models." Journal of Applied Econometrics 18 (1): 1-22. https://doi.org/10.1002/jae.659.

Bairoch, Paul. 1972. "Free Trade and European Economic Development in the 19th Century." European Economic Review 3 (3): 211-45. https://doi.org/10.1016/0014-2921(72)90005-0.

Baldwin, Richard. 2016. The Great Convergence. Harvard University Press.

Batista Jr, Paulo Nogueira. 1980. "Política Tarifária Britânica e Evolução Das Exportações Brasileiras Na Primeira Metade Do Século XIX.” Revista Brasileira de Economia 34 (2): 203-40.

Bethell, Leslie. 1970. The Abolition of the Brazilian Slave Trade: Britain, Brazil and the Slave Trade Question. Cambridge: Cambridge University Press.

Boianovsky, Mauro. 2013. "Friedrich List and the Economic Fate of Tropical Countries." History of Political Economy 45 (4): 647-91. https://doi.org/10.1215/00182702-2369958.

Brasil. 1830. Pauta D'Alfandega Do Rio de Janeiro. Rio de Janeiro: Typographia Imperial de Plancher Seignot. Buescu, Mircea. 1979. Brasil, disparidades de renda no passado: subsídios para o estudo dos problemas brasileiros. Rio de Janeiro: APEC.

Bulmer-Thomas, Victor. 2003. The Economic History of Latin America since Independence. 2 edition. Cambridge, U.K. ; New York: Cambridge University Press.

Cardoso, José Luís. 2008. "A abertura dos portos do Brasil em 1808: dos factos à doutrina." Ler História, no. 54: 9-31. https://doi.org/10.4000/lerhistoria.2342.

Christelow, Allan. 1947. "Great Britain and the Trades from Cadiz and Lisbon to Spanish America and Brazil, 1759-1783.” The Hispanic American Historical Review 27 (1): 2-29. https://doi.org/10.2307/2508589.

Coatsworth, John H., and Jeffrey G. Williamson. 2004. "Always Protectionist? Latin American Tariffs from Independence to Great Depression.” Journal of Latin American Studies 36 (2): 205-32. https://doi.org/10.1017/ S0022216X04007412.

Collier, Simon, and William F. Sater. 2004. A History of Chile, 1808-2002. Cambridge: Cambridge University Press.

Costeloe, Michael P. 1981. "Spain and the Latin American Wars of Independence: The Free Trade Controversy, 1810-1820." The Hispanic American Historical Review 61 (2): 209-34. https://doi.org/10.2307/2513829.

Crucini, Mario J. 1994. "Sources of Variation in Real Tariff Rates: The United States, 1900-1940.” The American Economic Review 84 (3): 732-43.

Davis, Ralph. 1979. The Industrial Revolution and British Overseas Trade. Leicester University Press.

Esteban, Javier Cuenca. 1995. "Further Evidence of Falling Prices of Cotton Cloth, 1768-1816.” The Economic History Review 48 (1): 145-50. https://doi.org/10.2307/2597875.

Esteban, Javier Cuenca. 1999. "Factory Costs, Market Prices, and Indian Calicos: Cotton Textile Prices Revisited, 1779-1831." The Economic History Review 52 (4): 749-55.

Farnie, D. A. 1979. The English Cotton Industry and the World Market: 1815-1896. Oxford University Press.

Fisher, John. 1981. "Imperial 'Free Trade' and the Hispanic Economy, 1778-1796.” Journal of Latin American Studies 13 (1): 21-56. https://doi.org/10.1017/S0022216X00006155.

Estud. Econ., São Paulo, vol.51 n.2, p.311-342, abr.-jun. 2021 
Fishlow, Albert. 1980. "Brazilian Development in Long-Term Perspective." The American Economic Review 70 (2): 102-8.

Fontoura, João Carneiro da. 1923. Documentação Para o Historico Das Tarifas Aduaneiras No Brasil 18081889. Rio de Janeiro: J. Leite.

Furtado, Celso. 2006. Formação econômica do Brasil. Companhia das Letras.

Galvarriato, Aurora Gómez. 2008. “The Mexican Cotton Textile Industry: An Overview.” 438. Documentos de Trabajo Des CIDE. Ciudad de México: CIDE.

Goebel, Dorothy Burne. 1938. "British Trade to the Spanish Colonies, 1796-1823." The American Historical Review 43 (2): 288-320. https://doi.org/10.2307/1839720.

Haber, Stephen, and Herbert S. Klein. 1997. "The Economic Consequences of Brazilian Independence.” In How Latin Amrica Fell Behind: Essays on the Economic Histories of Brazil and Mexico, 1800-1914, edited by Stephen H. Haber, 243-59. Stanford: Stanford University Press.

Harley, C. Knick. 1988. "Ocean Freight Rates and Productivity, 1740-1913: The Primacy of Mechanical Invention Reaffirmed.” The Journal of Economic History 48 (04): 851-876. https://doi.org/10.1017/S0022050700006641.

Harley, C. Knick. 1992. "The Antebellum American Tariff: Food Exports and Manufacturing." Explorations in Economic History 29 (4): 375-400. https://doi.org/10.1016/0014-4983(92)90001-D.

Harley, C. Knick. 1998. "Cotton Textile Prices and the Industrial Revolution.” The Economic History Review 51 (1): 49-83.

Harley, C. Knick. 1999. “Cotton Textile Prices Revisited: A Response to Cuenca Esteban.” The Economic History Review 52 (4): 756-65. https://doi.org/10.1111/1468-0289.00147.

Henderson, James. 1821. A History of the Brazil. London: Longman.

Hill, Henry. 1964. Uma Visão Do Comércio Do Brasil Em 1808. Salvador: Banco da Bahia.

Hoppit, Julian. 1990. "Counting the Industrial Revolution." The Economic History Review 43 (2): $173-93$. https://doi.org/10.2307/2596785.

Horace Say. 1839. Histoire des relations commerciales entre la France et le Brésil, considérations genérales sur les monnaies, les changes, les banques et le commerce extérieur par Horace Say. Paris: Editeur du dictionnaire du commerce et des marchandises.

Hunt's Merchants'Magazine and Commercial Review. 1848. “Commerce and Navigation of Brazil,” 1848,19 edition. Hathi Trust Digital Library.

IBGE. 1939. Anuário Estatístico Do Brasil 1939-40. Vol. Ano V. Instituto Brasileiro de Geografia e Estatística.

Imlah, Albert H. 1948. "Real Values in British Foreign Trade, 1798-1853." The Journal of Economic History 8 (02): 133-152. https://doi.org/10.1017/S0022050700069473.

Irwin, Douglas A. 2017. Clashing over Commerce: A History of US Trade Policy. University of Chicago Press. James, Gareth, Daniela Witten, Trevor Hastie, and Robert Tibshirani. 2013. An Introduction to Statistical Learning: With Applications in R. New York: Springer Science \& Business Media.

Kelly, Morgan, and Cormac Ó Gráda. 2018. “Speed under Sail during the Early Industrial Revolution.” DP12576. CEPR Discussion Paper.

Lago, Luiz Aranha Correa do. 1982. "Balança Comercial, Balanço de Pagamentos e Meio Circulante No Brasil No Segundo Império: Uma Nota Para Uma Revisão.” Revista Brasileira de Economia 36 (4): $489-508$.

Levy, Bárbara Maria, and Ana Maria Ribeiro de Andrade. 1985. "Fundamentos Do Sistema Bancário No Brasil: 1834-1860.” Estudos Econômicos (São Paulo) 15 (especial): 17-48.

Libby, Douglas Cole. 1991. "Proto-Industrialisation in a Slave Society: The Case of Minas Gerais." Journal of Latin American Studies 23 (1): 1-35. https://doi.org/10.1017/S0022216X00013341.

Lind, Michael. 2012. Land of Promise: An Economic History of the United States. 1st edition. New York: Harper. 
Lisboa, José da Silva. 1810. “Obervaçoens Sobre a Prosperidade Do Estados, Pelos Liberaes Principios Da Nova Legislação Do Brazil.” Correio Braziliense, 1810, V edition. Biblioteca Nacional Digital - Brasil.

Llorca-Jaña, Manuel. 2012. The British Textile Trade in South America in the Nineteenth Century. Cambridge ; New York: Cambridge University Press.

Lobo, Eulalia Maria Lahmeyer, Lucena Barbosa Madureira, Octavio Canavarros, Zakia Feres, and Sonia Gonçalves. 1971. "Evolução Dos Preços e Do Padrão de Vida No Rio de Janeiro, 1820-1930 - Resultados Preliminares." Revista Brasileira de Economia 25 (4): 235-66.

Lugar, Catherine. 1980. “The Merchant Community of Salvador, Bahia, 1780-1830.” Stony Brook: State University of New York at Stony Brook.

Luz, Nícia Villela. 1975. A luta pela industrialização do Brasil. São Paulo: Editora Alfa Omega.

Mamigonian, Beatriz G. 2017. Africanos livres: A abolição do tráfico de escravos no Brasil. São Paulo: Companhia das Letras.

Manchester, Alan Krebs. 1964. British Preeminence in Brazil: Its Rise and Decline : A Study in European Expansion. Octagon Books.

Martínez-Galarraga, Julio, and Marc Prat. 2016. "Wages, Prices, and Technology in Early Catalan Industrialization." The Economic History Review 69 (2): 548-74. https://doi.org/10.1111/ehr.12127.

Mawe, John. 1821. Travels In The Interior Of Brazil - 2nd Ed. London: Longman, Hurst, Rees, Orme and Brown.

Miller, Rory. 1995. Britain and Latin America in the Nineteenth and Twentieth Centuries. 1 edition. London; New York: Routledge.

North, Douglass. 1958. “Ocean Freight Rates and Economic Development 1730-1913.” The Journal of Economic History 18 (4): 537-55. https://doi.org/10.1017/S0022050700107739.

Oliveira Lima, Manuel de. 1908. Dom Joao VI no Brazil, 1808-1821. Rio de Janeiro: Typ. do Jornal do commercio. Pantaleão, Olga. 2003. “A Presença Inglesa.” In História Geral Da Civilização Brasileira, 3:75-114. Tomo II O Brasil Monárquico. Rio de Janeiro: Bertrand Brasil.

Pedreira, Jorge M. 2000. "From Growth to Collapse: Portugal, Brazil, and the Breakdown of the Old Colonial System (1760-1830)." Hispanic American Historical Review 80 (4): 839-64. https://doi.org/10.1215/0018216880-4-839.

Pedreira, Jorge Miguel Viana. 1994. Estrutura industrial e mercado colonial: Portugal e Brasil (1780-1830). Linda-a-Velha: DIFEL.

Peláez, Carlos Manuel, and Wilson Suzigan. 1981. História monetária do Brasil. Brasília: Editora Universidade de Brasília.

Pereira, Thales A. Zamberlan. 2017. "The Cotton Trade and Brazilian Foreign Commerce during the Industrial Revolution." São Paulo: Universidade de São Paulo.

Platt, D. C. M. 1971. "Problems in the Interpretation of Foreign Trade Statistics before 1914." Journal of Latin American Studies 3 (2): 119-30.

Platt, D. C. M. 1973. Latin America and British Trade, 1806-1914: The Merchant Adventurers. Harper \& Row. Prado Jr., Caio. 1972. História econômica do Brasil. Rio de Janeiro: Editôra Brasiliense.

Pryor, Arthur John. 1965. "Anglo-Brazilian Commercial Relations and the Evolution of Brazilian Tariff Policy, 1822-1850.” Thesis, University of Cambridge. https://www.repository.cam.ac.uk/handle/1810/251035.

Ratton, Diogo. 1821. Reflexões sobre o commercio, sobre as alfandegas, sobre os depositos, e sobre as pautas. Lisboa: Na Imprensa nacional.

Rego, Antônio José de Souza. 1869. Relatorio da $2^{a}$ Exposição Nacional de 1866. Vol. 2. Rio de Janeiro: Typographia Nacional.

Ricupero, Rubens. 2007. "O problema da Abertura dos Portos." In A abertura dos portos. São Paulo: Editora Senac São Paulo. 
Riello, Giorgio. 2013. Cotton: The Fabric That Made the Modern World. Cambridge University Press.

Rosenbloom, Joshua L. 2002. "Path Dependence and the Origins of Cotton Textile Manufacturing in New England.” Working Paper 9182. National Bureau of Economic Research. https://doi.org/10.3386/w9182.

Simonsen, Roberto. 1967. História Econômica Do Brasil (1500/1820). Rio de Janeiro: Brasiliana.

Socolow, Susan Migden. 1978. Merchants of Buenos Aires 1778-1810: Family and Commerce. Cambridge University Press.

Sousa, José António Soares de. 1970. “Aspectos Do Comércio Do Brasil e de Portugal No Fim Do Século XVIII e Começo Do Século XIX.” Revista Do Instituto Histórico e Geográfico Brasileiro 289: 3-111.

Spix, Johann Baptist von, Hannibal Evans Lloyd, and Karl Friedrich Philipp von Martius. 1824. Travels in Brazil, in the Years 1817-1820. Undertaken by Command of His Majesty the King of Bavaria. Reise in Brasilien.English. London: Longman, Hurst, Rees, Orme, Brown, and Green. http://catalog.hathitrust.org/Record/008649548.

Stein, Stanley J. 1979. Origens e evolução da indústria têxtil no Brasil: 1850-1950. Rio de Janeiro: Editora Campus. Stemmer, Juan E. Oribe. 1989. "Freight Rates in the Trade between Europe and South America, 1840-1914." Journal of Latin American Studies 21 (1): 23-59.

Sturz, Johann Jakob. 1837. A Review Financial, Statistical and Commercial of the Empire of Brazil and Its Resources ; Together with a Suggestion of the Expediency and Mode of Admitting Brazilian and Other Foreign Sugars Into Great Britain. London: E. Wilson.

Styles, John. 2016. "Fashion, Textiles and the Origins of Industrial Revolution." East Asian Journal of British History 5 (March): 161-89.

Temin, Peter. 1988. "Product Quality and Vertical Integration in the Early Cotton Textile Industry." The Journal of Economic History 48 (4): 891-907.

Temin, Peter. 1997. “Two Views of the British Industrial Revolution.” The Journal of Economic History 57 (1): 63-82.

Tena-Junguito, Antonio. 2010. "Bairoch Revisited: Tariff Structure and Growth in the Late Nineteenth Century." European Review of Economic History 14 (1): 111-43. https://doi.org/10.1017/S1361491609990062.

The Economist. 1843. "Expiring Commercial Treaty with the Brazils," September 2, 1843, 1 edition. www. economist.com/node/2002191.

Tibshirani, Robert, Guenther Walther, and Trevor Hastie. 2001. "Estimating the Number of Clusters in a Data Set via the Gap Statistic." Journal of the Royal Statistical Society: Series B (Statistical Methodology) 63 (2): 411-23. https://doi.org/10.1111/1467-9868.00293.

Turner, Benjamin Bannister. 1897. Chronicles of the Bank of England. London: Swan Sonnenschein \& Co.

Villela, André. 2005. "Política tarifária no II Reinado: evolução e impactos, 1850-1889." Nova Economia 15 (1). http://revistas.face.ufmg.br/index.php/novaeconomia/article/view/444.

Walker, Charles F. 1999. Smoldering Ashes: Cuzco and the Creation of Republican Peru, 1780-1840. Durham: Duke University Press.

Ward, Tony. 2004. "The Corn Laws and English Wheat Prices, 1815-1846." Atlantic Economic Journal 32 (3): 245-55. https://doi.org/10.1007/BF02299442.

Wilcken, Patrick. 2005. Império à deriva: a corte portuguesa no Rio de Janeiro, 1808-1821. Rio de Janeiro: Editora Objetiva.

Williamson, Jeffrey G. 1990. “The Impact of the Corn Laws Just Prior to Repeal.” Explorations in Economic History 27 (2): 123-56. https://doi.org/10.1016/0014-4983(90)90007-L.

Wright, Antônia Fernanda Pacca de Almeida. 1978. Desafio americano à preponderância britânica no Brasil, 1808-1850. São Paulo: Ed. Nacional. 